

\section{The Effects of EU Customs Union Integration on Turkish Intra-Industry Trade}

\author{
Dr. Gulcin Elif YUCEL
}

\section{Introduction}

After the Second World War, world trade has increased dramatically. Since the distribution of world trade has changed between countries, traditional trade theories have been questioned and different new trade theories have emerged. One of these new theories is the intra-industry trade (IIT) theory which has emerged after the observation of the rising pattern of international trade in the form of intra-industry trade. The development level of countries, the distance between countries and being a member of same bloc or having an economic integration with a country are some determinants of IIT. The results of many studies show that IIT is greater in the countries that experienced an economic integration.

The importance of Turkey-EU trade is especially marked after Turkey has started to adopt the liberalization measures by implementing the export-oriented policies in 1980s. In other words, from 1980 onwards, Turkey has changed its economic development policy from "import substitution" to "export-led growth" strategy. In 1996, Turkey-EU relations has taken another step after the establishment of CU which is one of the most important developments affecting Turkish economy. In January 1996, CU with EU countries was put into force. This integration process is a turning point in Turkey's foreign trade since Turkey has joined the large EU market which have high purchasing power and it is a considerable attempt towards trade liberalization. The $\mathrm{CU}$ between Turkey and EU has strengthened the economic and commercial ties and promoted an increase in the trade volume of Turkey with the EU. As stated by Doganer Gonel (2001), by entering a CU with the EU, Turkey has become the first and the only country to enter such an advanced form of economic integration without being a full member. When exports by main sectors are examined there seems to be a steady decrease in the share of exports of agricultural products. On the contrary, export of manufactured products increased its share in total exports from 1990 to 2006. This share rose from 67.7 percent in 1990 to 84.7 percent in 2004. There was a significant development in exports of Turkish manufactures, especially in the last 7 years (Seymen and Bilici, 2009).

The empirical analyses mostly focus on the economic effects of the CU with the EU on Turkey, especially changes in the volume of trade before and after CU. This paper is organized as follows. In the next section, the recent studies which investigate the effects of CU on Turkey's trade will be given. In the third section, Turkey-EU relationship will be briefly summarized. Then, the theoretical background of IIT is reviewed in the fourth section. In Section 5 and 6, our data, methodology, analyses and findings will be given, respectively.
Finally, Section 7 points out the main findings and concludes the study.

\section{Literature Survey}

As stated above, empirical analysis mostly focus on the economic effects of the CU with the EU on Turkey, especially changes in the volume of trade before and after $\mathrm{CU}$. The followings are some of these studies.

By using a partial equilibrium model, Halicioglu (1997) investigates the static effects of CU on Turkey's economy. Trade creation and trade diversion effects are also estimated which stem from tariff cuts. She recomputes these effects in cases of different trade blocs. Results show that $\mathrm{CU}$ is the second best after free trade.

Lohrmann (2002) examines Turkey's intra-industry trade with the EU in the 1990s. In this study SITC groups 5 to 8 are used and calculations are carried out for 1991, 1995, and 1999. As a result, the GL index shows an increase in IIT during the 1990s for Turkey vis-à-vis the EU, which should lead to the conclusion that adjustment costs of trade liberalization due to the $\mathrm{CU}$ might be tolerable. Also, the results indicate that the bulk of Turkey's trade with the EU is vertical. Finally, it is found that Turkey's trade with the EU is still disadvantaged in terms of quality.

In their study Seymen and Utkulu (2004) use cointegration method with error correction and causality mechanisms to clarify the level of price competitiveness of the Turkish firms towards the EU single market in aggregate level for the period 1963-2002. Their findings show that both the long-run price and income elasticities of Turkish exports to the EU are significantly reduced after the single market.

In her paper, Vatansever Deviren (2004) uses 3 digit level of SITC between Turkey and EU over the period 1993-2003 and classifies them according to either SITC manufactured product groups or technological structure. She concludes that IIT related with manufactured products and all products between Turkey and $\mathrm{EU}$ is below 0.50 value and because of that foreign trade between Turkey and EU exhibits an IIT structure.

Vergil (2004) examines the level and the structure of Turkey's IIT and tests the impact of the CU on Turkey's IIT level. The results reveal that the CU positively affects Turkey's IIT level.

Karaman and Ozkale (2006) aim to investigate Turkey's import demand function using an econometric panel data application. According to them a good reason for that is the removal of European Community's tariffs on its imports from Turkey in 1971 while Turkey waited the entering into force of the CU in 1996 for abolishing the trade barriers to the EU. Their analysis involves 19 EU countries and 16 non-EU countries which represent the $\% 81$ of the total non-EU import for the year 2000 . The chosen period is 1982-2004. Their methodology utilizes random effects model for the estimation. Their main findings show that Turkey's import demand is income elastic and price inelastic. Their empirical findings also indicate that $\mathrm{CU}$ has trade creation effects among some sectors and trade diversion effects among some others, while no effects at all could be calculated for the remaining. 
The study of Yenilmez and Kutlu (2005) aims to discuss the importance of IIT between Turkey and the EU countres. International trade flows between Turkey and the EU are grouped as primary products and industry products according to the SITC Rev.3 classification system and these groups are further divided into two groups to examine trade between Turkey and the EU before and after the $\mathrm{CU}$.

Aynagoz Cakmak and Yilmaz (2006) aim to find out foreign internal outsourcing exercised by Turkish manufacturers before and after the establishment of the CU. The outsourcing activity of Turkey with EU before and after the $\mathrm{CU}$ is calculated with the use of SITC Revision 2 trade classification system. As a result they find that for the period under examination there is a steady rise in the Turkish imports of parts and components from EU implying the neutrality of $\mathrm{CU}$ effect. Although the total value of imports of parts and components in 2004 has increased three times in respect to 1995 , they explain the upward trend by the general macroeconomic developments, such as changes in exchange rates and interest rates in Turkish economy rather than the formation of the CU between Turkey and EU.

Jackson (2007) presents an analytical framework, which has been applied to carry out an expost assessment of the impact of both shallow and deep integration elements of the Turkey-EU CU. The framework allows to draw out some assessment of the impact of the CU in terms of shallow integration. These assessments are mainly the followings: There has been an increase in Turkish imports originating from the EU suggestive of trade diversion; Turkish preferential access to the EU market appears to be a significant source of welfare gain for Turkey; Turkey and the EU have different patterns of trade - the EU imports a range of products moderately, whereas Turkey imports a fewer products some more intensively. The inclusion of Turkey in Common Agricultural Policy (CAP) is the one remaining area for traditional trade gains for Turkey.

The study of Kocyigit and Sen (2007) explains the extent of IIT in Turkey's foreign trade with the world and specialy its main trading partner, the EU. The results show that, as parallel to Turkey's trade with the world, Turkey's trade with the EU also getting towards to IIT type trading. Also, they find that the growth of IIT between Turkey and the EU shows the change of Turkish industrial base from low technology products group to high technology industries, specially since the CU agreement with the EU has been put into effect in 1996.

Neyapti et al. (2007) estimate import and export functions of Turkey with the EU and non-EU countries using panel data set. Their empirical findings indicate that CU has not only positively impacted on Turkey's trade, but also led to changes in the behaviour of both exports and imports. They also observe that the income elasticity of both imports and exports are lower for the EU countries, especially for the CU period.

Adam and Moutos (2008) provide an evidence that the EU-Turkey CU has had asymmetric effects on the trade between the EU-15 countries. They argue that the current EU-Turkey CU relation allows Turkey only limited access to the EU's internal market which implies that the larger part of the effects of goods market integration will materialise only after Turkey becomes a member of the EU

The paper of Seymen and Bilici (2009) studies how the concentration of foreign trade between Turkey and EU has been changed. In order to answer this question they use several trade concentration measures such as Trade Entropy Index, Concentration Ratio, Herfindahl-Hirshman Index and Bilateral Trade Intensity Index. Also, they examine the long-run trade relations (1969-2008) to see both trade creation and diversion effects of the $\mathrm{CU}$ and other factors that might influence country concentration of trade. Their emprical findings suggest that the effects of the $\mathrm{CU}$ on trade concentration of Turkey with the EU seems very limited and country concentration of trade more likely depends on the EU enlargement process.

\section{Turkey and EU}

Europe is Turkey's major trading partner of Turkey with a significant share in total trade flows. The share of Europe in Turkey's exports increased from 47 percent in 1980 to 50 percent in 1998, whereas the share of European imports increased from 33 percent to 52 percent in the same period. Turkey's principal trading partner in the Community is Germany, followed by Italy, France, the United Kingdom, and the Netherlands. After implementing an export-oriented policy in 1980, Turkey experienced a unique export boom. But imports have been always greater than exports. So, like other industrializing countries, Turkey faces a trade balance deficit. After the CU was put into force, Turkey's trade liberalization process has dramatically increased (Lohrmann, 2002). Until the formation of the CU, Turkish exports of textile and clothing products to the EU were subject to quota restrictions. As a result of the CU, the quotas facing Turkish exporters of textile and clothing products were eliminated (Togan, 2000). In a paper (Lohrmann, 2002) ranges Turkey's main export items to the EU market like the following: apparel and clothing, electrical machinery and equipment, boilers, textile yarns, iron, and steel man-made staple fibers. Main import items are machines, electrical machinery, road vehicles, plastics, organic chemicals, optical instruments, paper, and pharmaceutical products.

Turkey's application for association with the European Economic Community (EEC) was made in 1959. According to the Ankara Agreement which was signed in 1963, the association membership of Turkey was to be implemented in three stages: a preparatory stage, a transitional stage and a final stage (Togan, 2000). Quantitative restrictions on import were eliminated and consequently import tariff rates were reduced in various steps. In orher words, Turkey's tariffs and levies on imports of industrial products from the EU were eliminated. All tariffs from industrial products from Turkey abolished in 1971 with some exceptions. A transitional period of twenty-two years was agreed upon for Turkey. Turkey could not follow the schedule for tariff reductions because of severe economic problems in the late 1970s, but in the 1990s, Turkey made big efforts to complete the CU. They adopted the Common External Tariff on most industrial imports and eliminated most import surcharges (Lohrmann, 2002).The CU between Turkey and the EU has been in force since January 1996. 
Gokalp and Yildirim (2004) state that obligations arising from the $\mathrm{CU}$ were more than such a $\mathrm{CU}$ integration. The agreement embraces the liberalisation of tariffs and adoption of the EU's common external tariff for industrial products and the industrial components of processed agricultural products by Turkey and also a number of integration elements which includes the adoption of the Community's Commercial Policy towards third countries, the adoption of the free trade agreements with all the EU's preferential trade partners; co-operation on the harmonisation of agricultural policy, mutual minimisation of restriction on trade in services, harmonisation of Turkey's legislation to that of the EU in the area of competition policy, intellectual and industrial property rights, public procurement and technical barriers to trade. The aim of association membership was to increase agricultural and industrial export to the EEC market (Seymen and Bilici, 2009).

\section{Theoretical Framework of IIT}

Since the 1960s, the traditional trade theories (absolute and comparative advantage) have come under major criticism because they fail to explain trade in which countries both export and import within the same industrial category. The traditional Heckscher-Ohlin $(\mathrm{H}-$ O) theory, which is also known as factor proportions theory, cannot adequately explain the volume of simultaneous exports and imports within the same industry. Thus, trade economists were in a search of a new trade theory in order to explain the phenomenon of this simultaneous international trade. Xu (2002) states that, new trade theories which are based on imperfect competition and increasing returns to scale are specifically designed to explain the pattern of IIT whereas traditional theories of comparative advantage account only for inter-industry trade.

IIT is a new area of research on international trade beginning in the 1960 s and becoming important since 1980s. The "intra-industry trade" term was first used by Balassa (1966). ${ }^{1}$ The expansion of trade flows between countries can be of IIT type or inter-industry type. Inter-industry trade is considered as a one-way trade since the exchanged products belong to different industries. On the other hand, IIT is the two-way exchange of related products between nations with the same or similar factor intensities in production or that are close substitutes in demand. Grubel and Lloyd (2003) find this definition too restrictive and define IIT as an exchange between nations of all kinds of products that are closely related in supply or demand.

According to the results of empirical studies, it is observed that the share of IIT is growing. This stimulates the theoretical and empirical research on IIT. According to Crespo and Fontoura (2001), IIT has captured an enormous effort of research in three main areas: measuring the magnitude of the phenomenon ${ }^{2}$,

1 Balassa (1966), Grubell (1967) and many other call this type of trade as IIT. But IIT has been called variously such as "two-way trade" (Gray, 1973) and "trade overlap" (Finger, 1975).

2 See, Grubel and Lloyd (1975) and Brülhart (1994). developing theoretical explanations for its existence ${ }^{3}$ and finally evaluating the determinant factors arising from the theory ${ }^{4}$. In this study, based on our main purpose, the first and the last one has been covered.

There are two forms of IIT. The first one is HIIT that distinguishes between the exchange of competing or substitute products. The other one is VIIT that is the exchange of products at different stages in the processing of a final product (Grubel and Lloyd, 1975). Greenaway et al. (1994) make a common distinction between HIIT and VIIT. The former is seen between different varieties of a product while the latter is about the different qualities or levels of service provided by a product. ${ }^{5}$ HIIT is driven by economies of scale and occurs when products within similar qualities are differentiated. In this type of IIT, consumers can express their preferences for product variety. On the other hand, VIIT is defined as the exchange of similar goods of different quality which is driven by comparative advantage.

In general, HIIT is seen between the two-way trade of developed countries whereas VIIT is seen between developing and developed countries. However, recent empirical studies show that VIIT is dominant as compared to HIIT even among developed countries. ${ }^{6}$ Also, empirical literature of IIT points out the dominance of VIIT. ${ }^{7}$

\section{Data and Methodology}

\subsection{Data}

In this study, the IIT structure of Turkish international trade with selected trade blocs is tried to be examined based on 2-digit ISIC (Rev.3) data. The data were obtained from Turkish Statistical Institute (TURKSTAT) database. The study covers a period between 1990 to 2009. All calculations are made for the manufacturing sector. There are 22 manufacturing sectors

\footnotetext{
3 See, Krugman (1979) and Falvey (1981).

4 See, Helpman (1987) and Greenaway et al. (1994).

5 HIIT is derived from the "love of variety" model pioneered by Krugman and "most preferred variety" type of model pioneered by Lancaster (for details, see Greenaway et al. 1994). In other words, based on the work of Spence (1976) and Dixit and Stiglitz (1977) and popularized by Helpman and Krugman (1985), the love of variety (LOV) model has become a standard textbook model for IIT in horizontally differentiated products (for detail, please see $\mathrm{Xu}$ (2002)). On the other hand, VIIT is derived from the models of Falvey (1981) and others that emphasize product differentiation based on quality (for details, see Grubel and Lloyd, 2003).

6 See, Greenaway et al. (1994), Veeramani (1998), Aturupane et al. (1999) and $\mathrm{Hu}$ and Ma (1999).

7 For these studies, please see Greenaway et al. (1995), Aturupane et al. (1999), Durkin and Krygier (2000), Gullstrand (2002), Mora (2002), Crespo and Fontoura (2004) and Jensen and Lüthje (2008).
} 
and their sector codes range between 15 and 36. All quantities are measured in kilograms and all trade data are in \$US.

\subsection{Methodology}

Grubel and Lloyd (1975) state that there was a debate about the way in which IIT flows should be measured. The appropriate index or statistics to measure this trade was one of the main issues in discussions. Balassa (1966) was the first people who proposed the measure of the extent of intra-industry trade. In his measure exports of a given good are offset by imports of an equivalent good.

$B_{j}=\frac{|X j-M j|}{X j+M j}$

$X_{J}$ is the value of the exports of commodity $j$ by a country, and $M_{J}$ is the value of the "matching" imports. If there is no intra-industry trade $\left(X_{J}=0\right.$ or $M_{J}=$ 0 ), then $B_{J}=1$. But if there is perfectly matching intraindustry trade then $X_{J}=M_{J}$ and $B_{J}=0$.

The measure of Balassa has two drawbacks. First, it gives equal weight to all industries, that is irrespective of whether their share in total industry exports plus imports is large or small. Second, there is no correction for the aggregate trade imbalance (Grubel and Lloyd, 1975). Since Balassa index has not been found much favour, most studies generally use other indexes. There are two well-known measures of IIT both of which try to measure the trade overlap in a given sector. The Grubel-Lloyd (GL) index and Fontagné-Freudenberg (FF) index. In this study GL index is used to measure IIT shares of Turkey and its trade partners.

Grubel and Lloyd (1975) proposed a measure of IIT flows that is known as the GL index. The $G L$ index is a simple modification of the Balassa formula. It calculates the part of balanced trade (overlap between exports and imports) in all trade in a given industry $j$. The Grubel-Lloyd $(G L)$ index is written as,

$$
G L_{j}=\frac{(X j+M j)-|X j-M j|}{(X j+M j)}
$$

GL index varies between zero and one. If there is no intra-industry trade $\left(\mathrm{X}_{\mathrm{j}}=0\right.$ or $\left.\mathrm{M}_{\mathrm{j}}=0\right)$, it takes the value of zero and if there is perfectly matching intraindustry trade then $G L$ index takes the value of one.

After we calculate the shares of IIT by using GL index, we divide IIT into its horizontal and vertical components. In order to decompose IIT, the quality differences in exports and imports of a country are used. Since determining the qualities of commodities are very difficult, in empirical studies the product prices are generally used as indicators of quality. It is assumed that higher quality goods have higher prices (Stiglitz, 1987). Therefore, in order to determine the quality differences of exports and imports, export and import unit values are used. Differences in prices (unit values) reflect quality differences. This assumption is only acceptable with the most detailed trade data, where aggregation of different products within one product category is minimized. There are two most widely used methods for decomposing vertical and horizontal IIT: The first one is $G L$ index which is adopted by Greenaway, Hine and Milner (GHM) (1994) at first and the other way of measurement of VIIT and HIIT is the $F F$ index which is adopted firstly by Fontagné and Freudenberg (1997). Both methods rely on the same assumption regarding the association of price (actually unit values) with the quality of traded products. In this study, the decomposition has been done by using $G H M$ method. In the GHM case, a product exhibits HIIT when unit values of exports and imports lie between the interval and exhibits VIIT in the opposite case.

$$
\begin{aligned}
& \left.\begin{array}{ll}
1-\alpha \leq U V^{X_{i t}} / U V^{M_{i t}} \leq 1+\alpha & H I T \\
1-\alpha>U V^{X_{i t}} / U V^{M_{i t}} \text { or } U V^{X_{i t}} / U V^{M_{i t}}>1+\alpha & \text { VIIT }
\end{array}\right\} \text { GHM } \\
& \text { Since } \frac{1}{1+\alpha}>1-\alpha \text {, in the GHM case, }
\end{aligned}
$$

more products will be classified as VIIT (Azhar and Elliott, 2006). As $\alpha^{8}$ gets larger the difference between these two lower bounds will become larger. ${ }^{9}$ The vertical component of IIT can be broken down into high quality VIIT $\left(\right.$ VIIT $^{\mathrm{H}}$ ) and low quality VIIT $\left(\mathrm{VIIT}^{\mathrm{L}}\right)$. The lower bound of VIIT represents VIIT ${ }^{\mathrm{L}}$ whereas the upper bound represents the VIIT ${ }^{\mathrm{H}}$.

Traded products are considered to be similar (or horizontally differentiated) if the export and import unit values differ by less than $15 \%$. The transportation and insurance expenditures are estimated to constitute approximately $15 \%$ of the product prices. Therefore, in the calculations $\pm 15 \%$ are used. If this range is defined broader, the share of horizontal IIT will rise and the share of vertical IIT will fall.

\section{Analyses}

Here is the process of our analysis. Initially, ISIC Rev. 3, 2-digit foreign trade data obtained from TURKSTAT have been merged in a single ACCESS database. 15-36 coded manufacturing industry data have been selected. Then the missing sector name and code information in the data obtained from TURKSTAT have been completed and sub-totals have been calculated. All records have been rearranged as to be totally in 23 main sectors from 15 to 36. All records in KG/NUMBER, KG/LT, KG/M, KG/M2, KG/M3, KG/PAIR, KG/GRAM etc. have been converted to $\mathrm{KG}$ in order to obtain unit integrity. Records in volume units have been converted to KG multiplying them with an average density. Records which are not suitable to convert to $\mathrm{KG}$ have been excluded. (3330-Manufacture of watches and clocks; 3511- Building and repairing of ships, 3512- Building and repairing of pleasure and sporting boats). Then all records have been signed as EU and non-EU. GrubelLloyd index has been calculated for all records. Finally, the type of IIT is determined according to Greenaway, Hine and Milner (GHM) (1994).

\footnotetext{
8 " $\mathrm{a}$ " is used as a "dispersion factor" by Greenaway, Hine and Milner (1994).

9 see Erlat and Erlat, 2010
} 


\section{7. $\quad$ Findings}

Figure 1. Manufacturing Trade Deficit (1990-2009)

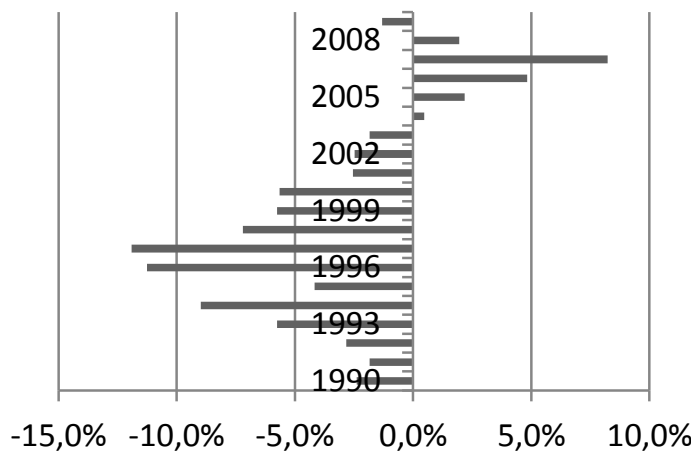

When we look at the import and export volume of EU-Turkey manufacturing trade, we see that Turkish imports from EU is greater than Turkish exports to EU. So, Turkish manufacturing trade has a trade deficit. As seen from the Figure 1, especially in 1994, 1996 and 1997, manufacturing trade deficit with EU countries is approximately $9 \%-12 \%$. On the other hand, there is a manufacturing trade surplus from 2004 to 2008.

Figure 2. The Import and Export Ratio of EU Countries to Non-EU Countries

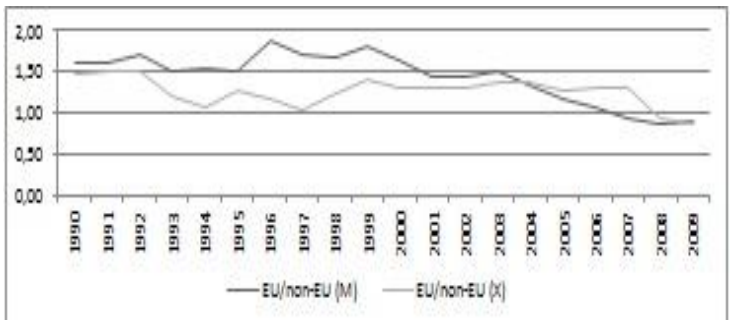

Figure 2 shows the import and export ratio of EU countries to non-EU countries. The declining pattern of the blue line indicates that imports from non-EU countries increases more than imports from EU countries. Figure 3 supports this situation. As seen below share of Turkish manufacturing trade with EU countries decreases. In other words, trade with non-EU countries increases.

\section{Figure 3. Share of Turkish Total Manufacturing} Trade with EU

\begin{tabular}{|c|c|}
\hline \multicolumn{2}{|c|}{70,096} \\
\hline \multirow{2}{*}{\multicolumn{2}{|c|}{$\begin{array}{l}60,0 \% \\
50,09 \%\end{array}$}} \\
\hline \multirow{2}{*}{\multicolumn{2}{|c|}{$\begin{array}{l}50,0 \% 6 \\
40,0 \% 6\end{array}$}} \\
\hline & \\
\hline \multicolumn{2}{|l|}{$\begin{array}{l}40,0 \% 6 \\
30,096\end{array}$} \\
\hline \multicolumn{2}{|l|}{$20,0 \%$} \\
\hline \multicolumn{2}{|l|}{$10,0 \%$} \\
\hline $0,0 \%$ & 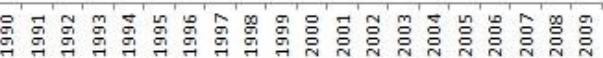 \\
\hline
\end{tabular}

Table 1 shows the top five EU countries for Turkish manufacturing exports. For a 20 -year period between 1990 and 2009, Germany is the big export partner of Turkey. The second and the third countries are always United Kingdom, Italy and France. Only their rank changes. On the other hand, Table 2 shows the top five EU countries for Turkish manufacturing imports. As seen from the table the dominance of Germany still holds. For this 20 year period, the second and the third countries are Italy and France, respectively.

Table 3 shows the top five sectors for Turkish manufacturing exports. For EU countries, the first three sectors are 18 (Manufacture of wearing apparel; dressing and dyeing of fur), 17 (Manufacture of textiles) and 15 (Manufacture of food products and beverages), respectively, until 1999. Beginning from 1999, the share of sector 34 (Manufacture of motor vehicles, trailers and semi-trailers) has increased from $4,6 \%$ to $13,7 \%$ and from 2005 to now this sector takes the first place in Turkish manufacturing exports. Sector 15 (Manufacture of food products and beverages), which has taken place in the top three sectors until 1999, does not take place in top five sectors until 2002.

Table 4 shows the top five sectors for Turkish manufacturing imports. Until 1999, sector 29 (Manufacture of machinery and equipment n.e.c.) is the dominant sector in manufacturing imports with EU countries. After 1999, sector 24 (Manufacture of chemicals and chemical products) takes the first place. On the other hand, import with non-EU countries concentrates on sectors 27 (Manufacture of basic metals) and 24 (Manufacture of chemicals and chemical products).

For non-EU countries sectors 17 (Manufacture of textiles) and 27 (Manufacture of basic metals) have the highest share. When we look at both of the EU and nonEU trade, sectors 15 (Manufacture of food products and beverages), 17 (Manufacture of textiles), 18 (Manufacture of wearing apparel; dressing and dyeing of fur), 27 (Manufacture of basic metals), 29 (Manufacture of machinery and equipment n.e.c.) and 34 (Manufacture of motor vehicles, trailers and semi-trailers) take part in top five of export and import.

Table 4 shows that imports from EU is approximately $60 \%$ of manufacturing trade. After 2004, imports decreases to $47 \%$. On the other hand, until 2008, exports to EU is $50 \%-60 \%$ of total manufacturing trade. But after 2008, manufacturing exports to EU have declined to $46 \%$.

For export to EU, table shows that shares of sectors 15 (Manufacture of food products and beverages), 18 (Manufacture of wearing apparel; dressing and dyeing of fur) and 24 (Manufacture of chemicals and chemical products) decline. On the other hand, the shares of sectors 25 (Manufacture of rubber and plastics products), 28 (Manufacture of fabricated metal products, except machinery and equipment), 29 (Manufacture of machinery and equipment n.e.c. ) and 34 (Manufacture of motor vehicles, trailers and semi-trailers) increase. The shares of sectors 16 (Manufacture of tobacco products), 20 (Manufacture of wood and of products of wood and cork, except furniture; manufacture of articles of straw and plaiting materials), 22 (Publishing, printing and 
reproduction of recorded media), 30 (Manufacture of office, accounting and computing machinery), 33 (Manufacture of medical, precision and optical instruments, watches and clocks) and 35 (Manufacture of other transport equipment) are very small and sometimes equal to zero. For imports from EU, table shows that shares of sectors 15 (Manufacture of food products and beverages), 24 (Manufacture of chemicals and chemical products) and 29 (Manufacture of machinery and equipment n.e.c.) decline. The shares of sectors 24,29 , and 34 are the highest ones but their shares have declined after the second period of 2000s. 
Table 1

TOP 5 COUNTRIES (EXPORTS)

\begin{tabular}{|c|c|c|c|c|c|c|c|c|c|c|}
\hline & 1990 & 1991 & 1992 & 1993 & 1994 & 1995 & 1996 & 1997 & 1998 & 1999 \\
\hline 1 & Germany & Germany & Germany & Germany & Germany & Germany & Germany & Germany & Germany & Germany \\
\hline 2 & Italy & Italy & Italy & UK & Italy & Italy & Italy & UK & UK & UK \\
\hline 3 & UK & UK & UK & France & UK & UK & UK & Italy & Italy & France \\
\hline 4 & France & France & France & Italy & France & France & France & France & France & Italy \\
\hline 5 & Netherlands & Netherlands & Netherlands & Netherlands & Netherlands & Netherlands & Netherlands & Netherlands & Netherlands & Netherlands \\
\hline & 2000 & 2001 & 2002 & 2003 & 2004 & 2005 & 2006 & 2007 & 2008 & 2009 \\
\hline 1 & Germany & Germany & Germany & Germany & Germany & Germany & Germany & Germany & Germany & Germany \\
\hline 2 & UK & Italy & UK & UK & UK & UK & UK & UK & UK & France \\
\hline 3 & Italy & UK & Italy & Italy & Italy & Italy & Italy & Italy & Italy & UK \\
\hline 4 & France & France & France & France & France & France & France & France & France & Italy \\
\hline 5 & Netherlands & Spain & Spain & Spain & Spain & Spain & Spain & Spain & Spain & Spain \\
\hline
\end{tabular}

Table 2

\begin{tabular}{|c|c|c|c|c|c|c|c|c|c|c|}
\hline \multicolumn{11}{|c|}{ TOP 5 COUNTRIES (IMPORTS) } \\
\hline & 1990 & 1991 & 1992 & 1993 & 1994 & 1995 & 1996 & 1997 & 1998 & 1999 \\
\hline 1 & Germany & Germany & Germany & Germany & Germany & Germany & Germany & Germany & Germany & Germany \\
\hline 2 & Italy & Italy & Italy & Italy & Italy & Italy & Italy & Italy & Italy & Italy \\
\hline 3 & France & France & France & France & France & France & France & France & France & France \\
\hline 4 & $\begin{array}{l}\text { UK } \\
\end{array}$ & $\begin{array}{l}\text { UK } \\
\end{array}$ & $\begin{array}{l}\text { UK } \\
\end{array}$ & $\begin{array}{l}\text { UK } \\
\end{array}$ & $\overline{\mathrm{UK}}$ & $\overline{\mathrm{UK}}$ & $\begin{array}{l}\text { UK } \\
\end{array}$ & $\overline{\mathrm{UK}}$ & $\begin{array}{l}\text { UK } \\
\end{array}$ & UK \\
\hline 5 & Bel-Lux & Bel-Lux & Netherlands & Netherlands & Netherlands & Bel-Lux & Netherlands & Spain & Netherlands & Sweden \\
\hline & 2000 & 2001 & 2002 & 2003 & 2004 & 2005 & 2006 & 2007 & 2008 & 2009 \\
\hline 1 & Germany & Germany & Germany & Germany & Germany & Germany & Germany & Germany & Germany & Germany \\
\hline 2 & Italy & Italy & Italy & Italy & Italy & Italy & Italy & Italy & Italy & Italy \\
\hline 3 & France & France & France & France & France & France & France & France & France & France \\
\hline 4 & UK & UK & UK & UK & UK & UK & UK & UK & Spain & Spain \\
\hline 5 & Spain & Spain & Spain & Spain & Spain & Spain & Spain & Spain & UK & UK \\
\hline
\end{tabular}

Dr.Gulcin Elif Yucel

$\mathrm{P}$ a g e |23| Emerging Markets Journal 


\begin{tabular}{|c|c|c|c|c|c|c|c|c|c|c|c|c|c|c|c|c|c|c|c|c|}
\hline \multirow{2}{*}{$s^{e^{c^{v^{*}}}} c^{d^{a^{e}}}$} & \multicolumn{20}{|c|}{ EXPORT PERCENTAGE OF SECTORS } \\
\hline & 1990 & 1991 & 1992 & 1993 & 1994 & 1995 & 1996 & 1997 & 1998 & 1999 & 2000 & 2001 & 2002 & 2003 & 2004 & 2005 & 2006 & 2007 & 2008 & 2009 \\
\hline 15 & $5,0 \%$ & $5,8 \%$ & $5,2 \%$ & $5,2 \%$ & $5,5 \%$ & $5,2 \%$ & $4,8 \%$ & $4,6 \%$ & $4,4 \%$ & $4,4 \%$ & $3,3 \%$ & $3,2 \%$ & $2,7 \%$ & $2,7 \%$ & $2,7 \%$ & $2,9 \%$ & $2,3 \%$ & $2,2 \%$ & $1,9 \%$ & $2,2 \%$ \\
\hline 16 & $0,0 \%$ & $0,0 \%$ & $0,0 \%$ & $0,0 \%$ & $0,1 \%$ & $0,3 \%$ & $0,2 \%$ & $0,1 \%$ & $0,0 \%$ & $0,0 \%$ & $0,0 \%$ & $0,0 \%$ & $0,1 \%$ & $0,1 \%$ & $0,0 \%$ & $0,0 \%$ & $0,0 \%$ & $0,0 \%$ & $0,0 \%$ & $0,0 \%$ \\
\hline 17 & $12,8 \%$ & $13,1 \%$ & $12,7 \%$ & $11,6 \%$ & $11,8 \%$ & $11,8 \%$ & $12,2 \%$ & $12,0 \%$ & $12,8 \%$ & $12,7 \%$ & $11,7 \%$ & $11,3 \%$ & $10,1 \%$ & $9,7 \%$ & $8,2 \%$ & $7,8 \%$ & $7,2 \%$ & $6,5 \%$ & $5,3 \%$ & $5,9 \%$ \\
\hline 18 & $22,7 \%$ & $23,4 \%$ & $24,1 \%$ & $23,3 \%$ & $18,1 \%$ & $19,7 \%$ & $17,8 \%$ & $16,2 \%$ & $17,0 \%$ & $15,8 \%$ & $15,1 \%$ & $13,6 \%$ & $14,3 \%$ & $13,7 \%$ & $11,8 \%$ & $11,2 \%$ & $10,1 \%$ & $9,5 \%$ & $7,5 \%$ & $8,2 \%$ \\
\hline 19 & $0,5 \%$ & $0,6 \%$ & $0,6 \%$ & $0,6 \%$ & $0,6 \%$ & $0,5 \%$ & $0,4 \%$ & $0,5 \%$ & $0,4 \%$ & $0,3 \%$ & $0,3 \%$ & $0,3 \%$ & $0,3 \%$ & $0,3 \%$ & $0,3 \%$ & $0,3 \%$ & $0,3 \%$ & $0,3 \%$ & $0,2 \%$ & $0,2 \%$ \\
\hline 20 & $0,1 \%$ & $0,1 \%$ & $0,1 \%$ & $0,1 \%$ & $0,1 \%$ & $0,1 \%$ & $0,1 \%$ & $0,1 \%$ & $0,1 \%$ & $0,1 \%$ & $0,1 \%$ & $0,1 \%$ & $0,1 \%$ & $0,1 \%$ & $0,1 \%$ & $0,1 \%$ & $0,1 \%$ & $0,1 \%$ & $0,1 \%$ & $0,1 \%$ \\
\hline 21 & $0,0 \%$ & $0,1 \%$ & $0,2 \%$ & $0,1 \%$ & $0,3 \%$ & $0,2 \%$ & $0,2 \%$ & $0,1 \%$ & $0,2 \%$ & $0,2 \%$ & $0,2 \%$ & $0,3 \%$ & $0,3 \%$ & $0,3 \%$ & $0,3 \%$ & $0,3 \%$ & $0,3 \%$ & $0,3 \%$ & $0,3 \%$ & $0,3 \%$ \\
\hline 22 & $0,1 \%$ & $0,1 \%$ & $0,2 \%$ & $0,3 \%$ & $0,2 \%$ & $0,1 \%$ & $0,1 \%$ & $0,1 \%$ & $0,1 \%$ & $0,1 \%$ & $0,1 \%$ & $0,1 \%$ & $0,1 \%$ & $0,1 \%$ & $0,1 \%$ & $0,1 \%$ & $0,1 \%$ & $0,1 \%$ & $0,1 \%$ & $0,1 \%$ \\
\hline 23 & $2,0 \%$ & $2,0 \%$ & $1,5 \%$ & $0,9 \%$ & $1,1 \%$ & $1,0 \%$ & $0,9 \%$ & $0,5 \%$ & $0,5 \%$ & $0,8 \%$ & $0,6 \%$ & $0,7 \%$ & $0,8 \%$ & $0,6 \%$ & $0,6 \%$ & $0,9 \%$ & $1,6 \%$ & $1,5 \%$ & $1,6 \%$ & $0,8 \%$ \\
\hline 24 & $3,6 \%$ & $3,1 \%$ & $2,7 \%$ & $2,5 \%$ & $2,7 \%$ & $2,9 \%$ & $2,4 \%$ & $2,2 \%$ & $2,1 \%$ & $2,2 \%$ & $2,4 \%$ & $2,2 \%$ & $2,0 \%$ & $1,8 \%$ & $1,9 \%$ & $1,6 \%$ & $1,8 \%$ & $1,6 \%$ & $1,5 \%$ & $1,4 \%$ \\
\hline 25 & $0,5 \%$ & $0,7 \%$ & $0,9 \%$ & $0,8 \%$ & $1,0 \%$ & $1,2 \%$ & $1,1 \%$ & $1,1 \%$ & $1,4 \%$ & $1,5 \%$ & $1,7 \%$ & $1,8 \%$ & $1,8 \%$ & $1,8 \%$ & $1,8 \%$ & $1,9 \%$ & $2,0 \%$ & $2,1 \%$ & $1,9 \%$ & $2,0 \%$ \\
\hline 26 & $2,4 \%$ & $2,4 \%$ & $2,5 \%$ & $1,9 \%$ & $1,8 \%$ & $1,9 \%$ & $1,9 \%$ & $1,9 \%$ & $1,9 \%$ & $2,0 \%$ & $2,1 \%$ & $2,2 \%$ & $2,2 \%$ & $2,0 \%$ & $1,8 \%$ & $1,6 \%$ & $1,4 \%$ & $1,4 \%$ & $1,2 \%$ & $1,3 \%$ \\
\hline 27 & $4,0 \%$ & $1,8 \%$ & $1,6 \%$ & $0,9 \%$ & $1,6 \%$ & $2,6 \%$ & $2,0 \%$ & $2,5 \%$ & $3,0 \%$ & $3,4 \%$ & $3,6 \%$ & $3,5 \%$ & $2,6 \%$ & $3,1 \%$ & $4,1 \%$ & $3,3 \%$ & $4,4 \%$ & $5,2 \%$ & $3,9 \%$ & $2,3 \%$ \\
\hline 28 & $0,7 \%$ & $0,8 \%$ & $1,0 \%$ & $0,9 \%$ & $0,8 \%$ & $0,9 \%$ & $1,1 \%$ & $1,0 \%$ & $1,2 \%$ & $1,4 \%$ & $1,4 \%$ & $1,4 \%$ & $1,4 \%$ & $1,8 \%$ & $1,9 \%$ & $2,0 \%$ & $2,0 \%$ & $2,0 \%$ & $2,0 \%$ & $1,9 \%$ \\
\hline 29 & $0,9 \%$ & $1,1 \%$ & $1,4 \%$ & $1,2 \%$ & $1,5 \%$ & $1,8 \%$ & $2,2 \%$ & $2,2 \%$ & $2,4 \%$ & $2,8 \%$ & $2,7 \%$ & $2,8 \%$ & $3,2 \%$ & $3,7 \%$ & $3,5 \%$ & $3,7 \%$ & $3,8 \%$ & $4,1 \%$ & $3,8 \%$ & $4,0 \%$ \\
\hline 30 & $0,2 \%$ & $0,1 \%$ & $0,1 \%$ & $0,0 \%$ & $0,0 \%$ & $0,0 \%$ & $0,1 \%$ & $0,1 \%$ & $0,1 \%$ & $0,2 \%$ & $0,1 \%$ & $0,1 \%$ & $0,1 \%$ & $0,0 \%$ & $0,0 \%$ & $0,0 \%$ & $0,0 \%$ & $0,1 \%$ & $0,1 \%$ & $0,1 \%$ \\
\hline 31 & $0,8 \%$ & $1,2 \%$ & $2,0 \%$ & $1,4 \%$ & $1,4 \%$ & $1,7 \%$ & $2,1 \%$ & $1,7 \%$ & $1,9 \%$ & $1,7 \%$ & $1,7 \%$ & $1,7 \%$ & $1,5 \%$ & $1,5 \%$ & $1,2 \%$ & $1,2 \%$ & $1,5 \%$ & $1,8 \%$ & $1,6 \%$ & $1,6 \%$ \\
\hline 32 & $2,0 \%$ & $2,4 \%$ & $1,7 \%$ & $1,1 \%$ & $1,0 \%$ & $1,1 \%$ & $1,1 \%$ & $1,7 \%$ & $3,0 \%$ & $2,7 \%$ & $3,1 \%$ & $2,8 \%$ & $4,1 \%$ & $3,9 \%$ & $4,4 \%$ & $4,3 \%$ & $3,6 \%$ & $2,5 \%$ & $1,6 \%$ & $1,8 \%$ \\
\hline 33 & $0,0 \%$ & $0,0 \%$ & $0,2 \%$ & $0,1 \%$ & $0,1 \%$ & $0,1 \%$ & $0,1 \%$ & $0,1 \%$ & $0,1 \%$ & $0,1 \%$ & $0,1 \%$ & $0,1 \%$ & $0,1 \%$ & $0,1 \%$ & $0,1 \%$ & $0,1 \%$ & $0,1 \%$ & $0,2 \%$ & $0,1 \%$ & $0,1 \%$ \\
\hline 34 & $1,0 \%$ & $1,2 \%$ & $1,4 \%$ & $1,2 \%$ & $1,6 \%$ & $2,6 \%$ & $2,6 \%$ & $1,6 \%$ & $2,0 \%$ & $4,6 \%$ & $4,6 \%$ & $7,1 \%$ & $7,8 \%$ & $9,2 \%$ & $11,5 \%$ & $11,3 \%$ & $12,3 \%$ & $13,7 \%$ & $11,9 \%$ & $10,7 \%$ \\
\hline 35 & $0,0 \%$ & $0,0 \%$ & $0,0 \%$ & $0,1 \%$ & $0,1 \%$ & $0,1 \%$ & $0,2 \%$ & $0,3 \%$ & $0,3 \%$ & $0,9 \%$ & $1,0 \%$ & $0,6 \%$ & $0,2 \%$ & $0,5 \%$ & $0,6 \%$ & $0,3 \%$ & $0,3 \%$ & $0,3 \%$ & $0,2 \%$ & $0,2 \%$ \\
\hline 36 & $0,2 \%$ & $0,2 \%$ & $0,3 \%$ & $0,3 \%$ & $0,4 \%$ & $0,4 \%$ & $0,5 \%$ & $0,4 \%$ & $0,6 \%$ & $0,7 \%$ & $0,8 \%$ & $0,8 \%$ & $1,0 \%$ & $1,1 \%$ & $1,2 \%$ & $1,2 \%$ & $1,2 \%$ & $1,2 \%$ & $1,1 \%$ & $1,1 \%$ \\
\hline TOTAL & $59,5 \%$ & $60,0 \%$ & $60,1 \%$ & $54,6 \%$ & $51,9 \%$ & $56,2 \%$ & $54,2 \%$ & $51,1 \%$ & $55,5 \%$ & $58,7 \%$ & $56,6 \%$ & $56,7 \%$ & $56,7 \%$ & $58,1 \%$ & $58,0 \%$ & $56,1 \%$ & $56,4 \%$ & $56,7 \%$ & $48,0 \%$ & $46,4 \%$ \\
\hline
\end{tabular}

The Effects of EU Customs Union Integration on Turkish Intra-Industry Trade 
Table 4

\begin{tabular}{|c|c|c|c|c|c|c|c|c|c|c|c|c|c|c|c|c|c|c|c|c|}
\hline & \multicolumn{20}{|c|}{ IMPORT PERCENTAGE OF SECTORS } \\
\hline & 1990 & 1991 & 1992 & 1993 & 1994 & 1995 & 1996 & 1997 & 1998 & 1999 & 2000 & 2001 & 2002 & 2003 & 2004 & 2005 & 2006 & 2007 & 2008 & 2009 \\
\hline 15 & $0 \%$ & $1,7 \%$ & $\%$ & $1,5 \%$ & $1,9 \%$ & $2,8 \%$ & $2,2 \%$ & $1,7 \%$ & $1,5 \%$ & $1,4 \%$ & $1,2 \%$ & $1,4 \%$ & $1,5 \%$ & $1,3 \%$ & $1,1 \%$ & $1,0 \%$ & $0,9 \%$ & $0,8 \%$ & $8 \%$ & $0,9 \%$ \\
\hline 16 & $1 \%$ & $0,1 \%$ & $0,1 \%$ & $0,1 \%$ & $0,1 \%$ & $0,0 \%$ & $0,0 \%$ & $0,0 \%$ & $0,0 \%$ & $0,0 \%$ & $0,0 \%$ & $0,0 \%$ & $0,0 \%$ & $0,1 \%$ & $0,1 \%$ &, $1 \%$ & $0,1 \%$ & $0,1 \%$ &, $1 \%$ & $0,1 \%$ \\
\hline 17 & $2 \%$ & $1,1 \%$ & $1,5 \%$ & $1,4 \%$ & $1,8 \%$ & $2,0 \%$ & $2,6 \%$ & $2,6 \%$ & $2,5 \%$ & $2,5 \%$ & $2,0 \%$ & $2,6 \%$ & $2,7 \%$ & $2,3 \%$ & $1,8 \%$ & $1,5 \%$ & $1,3 \%$ & $1,2 \%$ & $1,0 \%$ & $1,0 \%$ \\
\hline 18 & $1 \%$ & $0,1 \%$ & $0,1 \%$ & $0,2 \%$ & $0,2 \%$ & $0,2 \%$ & $0,5 \%$ & $0,5 \%$ & $0,5 \%$ & $0,4 \%$ & $0,4 \%$ & $0,6 \%$ & $0,6 \%$ & $0,5 \%$ & $0,4 \%$ & $0,3 \%$ & $0,3 \%$ & $0,3 \%$ & $0,3 \%$ & $0,3 \%$ \\
\hline 19 & $6 \%$ & $0,5 \%$ & $0,5 \%$ & $0,6 \%$ & $0,6 \%$ & $0,5 \%$ & $0,6 \%$ & $0,6 \%$ & $0,5 \%$ & $0,4 \%$ & $0,4 \%$ & $0,5 \%$ & $0,4 \%$ & $0,4 \%$ & $0,3 \%$ & $0,2 \%$ & $0,3 \%$ & $0,2 \%$ &, $2 \%$ & $0,2 \%$ \\
\hline 20 & $1 \%$ & $0,2 \%$ & $0,1 \%$ & $0,2 \%$ & $0,1 \%$ & $0,1 \%$ & $0,2 \%$ & $0,2 \%$ & $0,2 \%$ & $0,2 \%$ & $0,3 \%$ & $0,2 \%$ & $0,2 \%$ & $0,3 \%$ & $0,3 \%$ & $0,4 \%$ & $0,3 \%$ & $0,3 \%$ & $0,3 \%$ & $0,3 \%$ \\
\hline 21 & $1,2 \%$ & $1,4 \%$ & $1,4 \%$ & $1,6 \%$ & $1,4 \%$ & $1,7 \%$ & $1,5 \%$ & $1,5 \%$ & $1,5 \%$ & $1,7 \%$ & $1,5 \%$ & $1,7 \%$ & $1,7 \%$ & $1,7 \%$ & $1,5 \%$ & $1,4 \%$ & $1,4 \%$ & $1,3 \%$ & $1,2 \%$ & $1,4 \%$ \\
\hline 22 & $0,3 \%$ & $0,3 \%$ & $0,4 \%$ & $0,6 \%$ & $0,5 \%$ & $0,3 \%$ & $0,3 \%$ & $0,3 \%$ & $0,3 \%$ & $0,3 \%$ & $0,4 \%$ & $0,6 \%$ & $0,4 \%$ & $0,3 \%$ & $0,2 \%$ & $0,3 \%$ & $0,2 \%$ & $0,2 \%$ &, $2 \%$ & $0,3 \%$ \\
\hline 23 & $0,9 \%$ & $1,2 \%$ & $0,8 \%$ & $1,1 \%$ & $1,3 \%$ & $0,8 \%$ & $1,1 \%$ & $0,9 \%$ & $0,9 \%$ & $1,4 \%$ & $1,7 \%$ & $0,9 \%$ & $0,7 \%$ & $0,9 \%$ & $0,9 \%$ & $1,0 \%$ & $1,5 \%$ & $1,3 \%$ & $2,1 \%$ & $1,8 \%$ \\
\hline 24 & $13,3 \%$ & $13,1 \%$ & $13,7 \%$ & $11,8 \%$ & $13,8 \%$ & $14,2 \%$ & $12,3 \%$ & $12,2 \%$ & $12,0 \%$ & $13,8 \%$ & $12,2 \%$ & $14,2 \%$ & $13,9 \%$ & $13,3 \%$ & $12,3 \%$ & $11,8 \%$ & $11,0 \%$ & $10,0 \%$ & $9,8 \%$ & $10,7 \%$ \\
\hline 25 & $1,3 \%$ & $1,4 \%$ & $1,6 \%$ & $1,6 \%$ & $1,6 \%$ & $1,8 \%$ & $1,8 \%$ & $1,8 \%$ & $1,9 \%$ & $2,1 \%$ & $1,7 \%$ & $2,0 \%$ & $2,1 \%$ & $1,9 \%$ & $1,7 \%$ & $1,6 \%$ & $1,5 \%$ & $1,5 \%$ & $1,5 \%$ & $1,6 \%$ \\
\hline 26 & $1,3 \%$ & $1,2 \%$ & $1,2 \%$ & $1,0 \%$ & $1,2 \%$ & $1,1 \%$ & 1,19 & $0,9 \%$ & $1,0 \%$ & $0,9^{\circ}$ & $0,7 \%$ & $0,7 \%$ & $0,8 \%$ & $0,6 \%$ & $0,6 \%$ & $0,6 \%$ & $0,7 \%$ & $0,6 \%$ & $0,5 \%$ & $0,5 \%$ \\
\hline 27 & $6,6 \%$ & $6,0 \%$ & $6,0 \%$ & $5,7 \%$ & $5,2 \%$ & $5,3 \%$ & $4,6 \%$ & $4,2 \%$ & $3,6 \%$ & $3,0 \%$ & $3,4 \%$ & $4,1 \%$ & $4,3 \%$ & $5,3 \%$ & $4,7 \%$ & $4,7 \%$ & $4,6 \%$ & $4,7 \%$ & $4,4 \%$ & $4,0 \%$ \\
\hline 28 & $1,5 \%$ & $2,1 \%$ & $2,2 \%$ & $2,0 \%$ & $1,8 \%$ & $1,9 \%$ & $2,1 \%$ & $1,8 \%$ & $1,9 \%$ & $1,9 \%$ & $1,5 \%$ & $2,1 \%$ & $2,1 \%$ & $1,6 \%$ & $1,5 \%$ & $1,5 \%$ & $1,5 \%$ & $1,4 \%$ & $1,4 \%$ & $1,3 \%$ \\
\hline 29 & $15,2 \%$ & $16,2 \%$ & $15,4 \%$ & $14,8 \%$ & $14,4 \%$ & $13,4 \%$ & $16,4 \%$ & $14,5 \%$ & $14,1 \%$ & $10,5 \%$ & $9,2 \%$ & $10,0 \%$ & $11,0 \%$ & $10,1 \%$ & $8,8 \%$ & $8,8 \%$ & $8,4 \%$ & $8,1 \%$ & $7,1 \%$ & $7,1 \%$ \\
\hline 30 & $1,5 \%$ & $1,6 \%$ & $1,6 \%$ & $1,4 \%$ & $1,2 \%$ & $1,1 \%$ & $1,1 \%$ & $1,3 \%$ & $1,4 \%$ & $1,7 \%$ & $1,7 \%$ & $1,2 \%$ & $1,1 \%$ & $0,8 \%$ & $0,6 \%$ & $0,6 \%$ & $0,5 \%$ & $0,5 \%$ & $0,4 \%$ & $0,4 \%$ \\
\hline 31 & $3,2 \%$ & $3,8 \%$ & $3,7 \%$ & $3,2 \%$ & $3,3 \%$ & $2,7 \%$ & $2,6 \%$ & $2,8 \%$ & $3,1 \%$ & $3,6 \%$ & $2,6 \%$ & $2,8 \%$ & $2,9 \%$ & $2,4 \%$ & $2,2 \%$ & $2,2 \%$ & $2,2 \%$ & $2,4 \%$ & $2,7 \%$ & $3,4 \%$ \\
\hline 32 & $2,0 \%$ & $2,4 \%$ & $1,9 \%$ & $1,9 \%$ & $2,5 \%$ & $2,6 \%$ & $2,5 \%$ & $3,3 \%$ & $4,4 \%$ & $7,4 \%$ & $7,0 \%$ & $4,6 \%$ & $4,0 \%$ & $3,4 \%$ & $3,1 \%$ & $2,5 \%$ & $2,0 \%$ & $1,7 \%$ & $1,3 \%$ & $1,7 \%$ \\
\hline 33 & $1,9 \%$ & $2,0 \%$ & $1,9 \%$ & $1,9 \%$ & $2,2 \%$ & $1,6 \%$ & $1,7 \%$ & $1,6 \%$ & $1,8 \%$ & $1,8 \%$ & $1,5 \%$ & $1,6 \%$ & $1,5 \%$ & $1,3 \%$ & $1,4 \%$ & $1,4 \%$ & $1,3 \%$ & $1,3 \%$ & $1,3 \%$ & $1,3 \%$ \\
\hline 34 & $5,8 \%$ & $4,7 \%$ & $5,9 \%$ & $6,5 \%$ & $4,5 \%$ & $5,2 \%$ & $7,2 \%$ & $8,4 \%$ & $7,8 \%$ & $8,1 \%$ & $11,4 \%$ & $6,0 \%$ & $6,3 \%$ & $10,1 \%$ & $12,5 \%$ & $11,0 \%$ & $10,0 \%$ & $9,2 \%$ & $8,1 \%$ & $7,9 \%$ \\
\hline 35 & $0,3 \%$ & $0,2 \%$ & $0,3 \%$ & $0,7 \%$ & $0,8 \%$ & $0,3 \%$ & $2,0 \%$ & $1,1 \%$ & $0,6 \%$ & $0,8 \%$ & $0,7 \%$ & $0,7 \%$ & $0,3 \%$ & $0,4 \%$ & $0,8 \%$ & $0,3 \%$ & $1,0 \%$ & $0,7 \%$ & $0,7 \%$ & $0,9 \%$ \\
\hline 36 & $0,4 \%$ & $0,5 \%$ & $0,6 \%$ & $0,5 \%$ & $0,5 \%$ & $0,7 \%$ & $0,8 \%$ & $0,8 \%$ & $0,8 \%$ & $0,8 \%$ & $0,7 \%$ & $0,9 \%$ & $0,8 \%$ & $0,9 \%$ & $0,8 \%$ & $0,6 \%$ & $0,7 \%$ & $0,8 \%$ & $0,7 \%$ & $0,6 \%$ \\
\hline TAAL & $61,9 \%$ & $61,8 \%$ & $63,0 \%$ & $60,4 \%$ & $60,9 \%$ & $60,3 \%$ & $65,4 \%$ & $63,0 \%$ & $62,7 \%$ & $64,4 \%$ & $62,3 \%$ & $59,2 \%$ & $59,2 \%$ & $60,0 \%$ & $57,5 \%$ & $53,9 \%$ & $51,6 \%$ & $48,4 \%$ & $46,1 \%$ & $47,7 \%$ \\
\hline
\end{tabular}

Dr.Gulcin Elif Yucel

$\mathrm{P}$ a g e |25| Emerging Markets Journal 
Figure 4. GL Index For EU

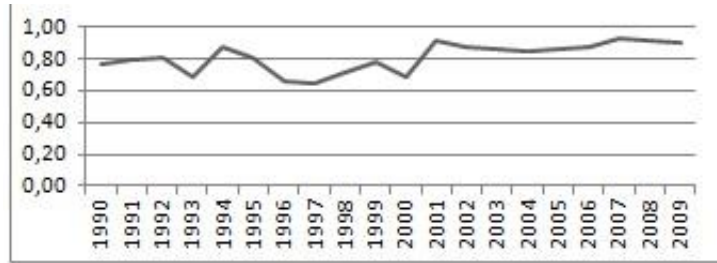

The Figure 4 above shows that the value of GL index is high for EU-Turkey manufacturing trade. As seen from below, especially after 2001 the value of GL is between $85 \%-95 \%$. Also, the type of IIT is low-quality VIIT to a large extent. 17 years out of 20 shows lowquality VIIT.

Table 5: Type of IIT (Full period)

\begin{tabular}{|c|c|c|}
\hline Year & GL for EU & V_H \\
\hline $\mathbf{1 9 9 0}$ & 0,77 & VIIT(L) \\
\hline $\mathbf{1 9 9 1}$ & 0,79 & VIIT(L) \\
\hline $\mathbf{1 9 9 2}$ & 0,81 & VIIT(L) \\
\hline $\mathbf{1 9 9 3}$ & 0,69 & HIIT \\
\hline $\mathbf{1 9 9 4}$ & 0,88 & VIIT(L) \\
\hline $\mathbf{1 9 9 5}$ & 0,80 & VIIT(L) \\
\hline $\mathbf{1 9 9 6}$ & 0,66 & VIIT(L) \\
\hline $\mathbf{1 9 9 7}$ & 0,65 & VIIT(L) \\
\hline $\mathbf{1 9 9 8}$ & 0,71 & VIIT(L) \\
\hline $\mathbf{1 9 9 9}$ & 0,78 & VIIT(L) \\
\hline $\mathbf{2 0 0 0}$ & 0,69 & VIIT(L) \\
\hline $\mathbf{2 0 0 1}$ & 0,92 & VIIT(L) \\
\hline $\mathbf{2 0 0 2}$ & 0,88 & VIIT(L) \\
\hline $\mathbf{2 0 0 3}$ & 0,87 & VIIT(L) \\
\hline $\mathbf{2 0 0 4}$ & 0,85 & VIIT(L) \\
\hline $\mathbf{2 0 0 5}$ & 0,86 & VIIT(L) \\
\hline $\mathbf{2 0 0 6}$ & 0,88 & VIIT(L) \\
\hline $\mathbf{2 0 0 7}$ & 0,93 & VIIT(L) \\
\hline $\mathbf{2 0 0 8}$ & 0,92 & HIIT \\
\hline $\mathbf{2 0 0 9}$ & 0,91 & HIIT \\
\hline
\end{tabular}

Table 6: Type of IIT (3-period)

\begin{tabular}{|c|c|c|}
\hline Period & GL & V_H \\
\hline $1990-1995$ & 0,79 & VIIT(L) \\
\hline $1996-2001$ & 0,73 & VIIT(L) \\
\hline $2002-2007$ & 0,88 & VIIT(L) \\
\hline
\end{tabular}

In table 6, we divide 1990-2007 period into 3 sub-period. Before and after Customs Union period the type of IIT has not changed. The dominance of low-quality VIIT still holds for EU-Turkey manufacturing trade. Also, in table 7 , the number of sectors for these 3 sub-period supports the dominance of low-quality VIIT.
Table 7: Number of Sectors

\begin{tabular}{|c|c|c|}
\hline Period & V_H & Sector Number \\
\hline \multirow{3}{*}{$1990-1995$} & VIIT(H) & 5 \\
\cline { 2 - 3 } & VIIT(L) & 17 \\
\cline { 2 - 3 } & HIIT & \\
\hline \multirow{3}{*}{$1996-2001$} & VIIT(H) & 1 \\
\cline { 2 - 3 } & VIIT(L) & 16 \\
\cline { 2 - 3 } & HIIT & 5 \\
\hline \multirow{3}{*}{$2002-2007$} & VIIT(H) & 3 \\
\cline { 2 - 3 } & VIIT(L) & 17 \\
\cline { 2 - 3 } & HIIT & 2 \\
\hline
\end{tabular}

Figure 5. GL Index (3-period)

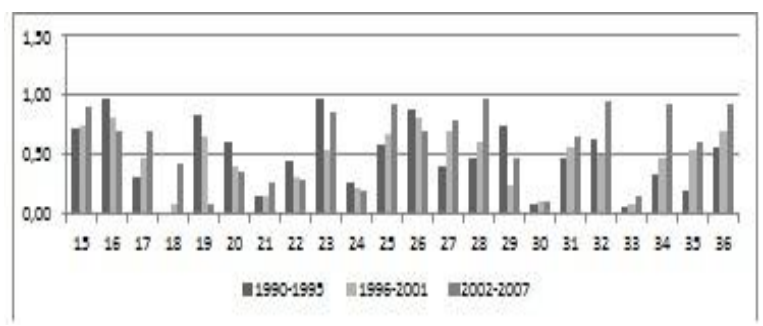

Graph 5 shows the values of GL index of manufacturing sectors for 3 sub-periods. According to the GL index values, after Customs Union, in sectors 15 (Manufacture of food products and beverages), 16 (Manufacture of tobacco products), 20 (Manufacture of wood and of products of wood and cork, except furniture; manufacture of articles of straw and plaiting materials), 22 (Publishing, printing and reproduction of recorded media) and 24 (Manufacture of chemicals and chemical products) IIT is decreasing. In sectors 21 (Manufacture of paper and paper products), 25 (Manufacture of rubber and plastics products), 27 (Manufacture of basic metals), 28 (Manufacture of fabricated metal products, except machinery and equipment), 30 (Manufacture of office, accounting and computing machinery), 31 (Manufacture of electrical machinery and apparatus n.e.c.), 33 (Manufacture of medical, precision and optical instruments, watches and clocks), 34 (Manufacture of motor vehicles, trailers and semi-trailers), 35 (Manufacture of other transport equipment) and 36 (Manufacture of furniture; manufacturing n.e.c.) IIT is increasing.

Table 8 shows the number of manufacturing sectors before and after Customs Union. According to the figures, in sectors 16 (Manufacture of tobacco products) and 21 (Manufacture of paper and paper products), lowquality VIIT has turned to be high-quality VIIT after Customs Union. Conversely, in sectors 17 (Manufacture of textiles), 22 (Publishing, printing and reproduction of recorded media) and 35 (Manufacture of other transport equipment), high-quality VIIT has turned to be lowquality VIIT. For the other sectors nothing have changed after Customs Union. 
Table 8: Number of Sectors before and after Customs Union

\begin{tabular}{|c|c|c|c|c|c|c|}
\hline Period & ISIC & V_H & & Period & ISIC & V_H \\
\hline $1990-1995$ & 15 & VIIT(H) & & $1990-1995$ & 26 & VIIT(L) \\
\hline $1996-2001$ & 15 & HIIT & & $1996-2001$ & 26 & VIIT(L) \\
\hline $2002-2007$ & 15 & HIIT & & $2002-2007$ & 26 & VIIT(L) \\
\hline $1990-1995$ & 16 & VIIT(L) & & $1990-1995$ & 27 & VIIT(L) \\
\hline $1996-2001$ & 16 & VIIT(H) & & $1996-2001$ & 27 & VIIT(L) \\
\hline $2002-2007$ & 16 & VIIT(H) & & $2002-2007$ & 27 & VIIT(L) \\
\hline $1990-1995$ & 17 & VIIT(H) & & $1990-1995$ & 28 & VIIT(L) \\
\hline $1996-2001$ & 17 & HIIT & & $1996-2001$ & 28 & VIIT(L) \\
\hline $2002-2007$ & 17 & VIIT(L) & & $2002-2007$ & 28 & VIIT(L) \\
\hline $1990-1995$ & 18 & VIIT(L) & & $1990-1995$ & 29 & VIIT(L) \\
\hline $1996-2001$ & 18 & VIIT(L) & & $1996-2001$ & 29 & VIIT(L) \\
\hline $2002-2007$ & 18 & VIIT(L) & & $2002-2007$ & 29 & VIIT(L) \\
\hline $1990-1995$ & 19 & VIIT(L) & & $1990-1995$ & 30 & VIIT(L) \\
\hline $1996-2001$ & 19 & VIIT(L) & & $1996-2001$ & 30 & VIIT(L) \\
\hline $2001-2007$ & 19 & VIIT(L) & & $2002-2007$ & 30 & HIIT \\
\hline $1990-1995$ & 20 & VIIT(H) & & $1990-1995$ & 31 & VIIT(L) \\
\hline $1996-2001$ & 20 & HIIT & & $1996-2001$ & 31 & VIIT(L) \\
\hline $2002-2007$ & 20 & VIIT(H) & & $2002-2007$ & 31 & VIIT(L) \\
\hline $1990-1995$ & 21 & VIIT(L) & & $1990-1995$ & 32 & VIIT(L) \\
\hline $1996-2001$ & 21 & HIIT & & $1996-2001$ & 32 & VIIT(L) \\
\hline $2002-2007$ & 21 & VIIT(H) & & $2002-2007$ & 32 & VIIT(L) \\
\hline $1990-1995$ & 22 & VIIT(H) & & $1990-1995$ & 33 & VIIT(L) \\
\hline $1996-2001$ & 22 & VIIT(L) & & $1996-2001$ & 33 & VIIT(L) \\
\hline $2002-2007$ & 22 & VIIT(L) & & $2002-2007$ & 33 & VIIT(L) \\
\hline $1990-1995$ & 23 & VIIT(L) & & $1990-1995$ & 34 & VIIT(L) \\
\hline $1996-2001$ & 23 & VIIT(L) & & $1996-2001$ & 34 & VIIT(L) \\
\hline $2002-2007$ & 23 & VIIT(L) & & $2002-2007$ & 34 & VIIT(L) \\
\hline $1990-1995$ & 24 & VIIT(L) & & $1990-1995$ & 35 & VIIT(H) \\
\hline $1996-2001$ & 24 & VIIT(L) & & $1996-2001$ & 35 & HIIT \\
\hline $2002-2007$ & 24 & VIIT(L) & & $2002-2007$ & 35 & VIIT(L) \\
\hline $1990-1995$ & 25 & VIIT(L) & & $1990-1995$ & 36 & VIIT(L) \\
\hline $1996-2001$ & 25 & VIIT(L) & & $1996-2001$ & 36 & VIIT(L) \\
\hline $2002-2007$ & 25 & VIIT(L) & & $2002-2007$ & 36 & VIIT(L) \\
\hline & & & & & & \\
\hline
\end{tabular}




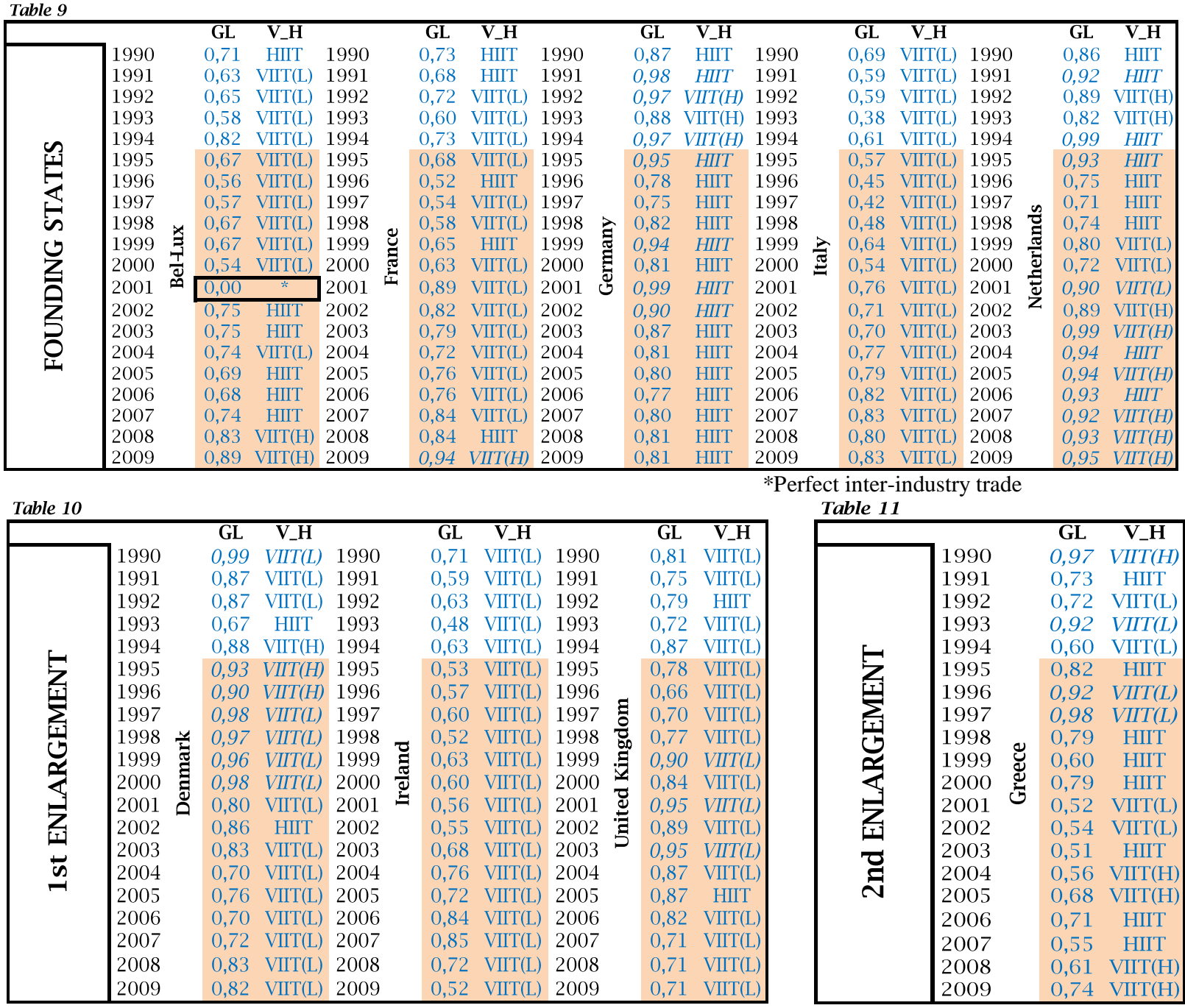

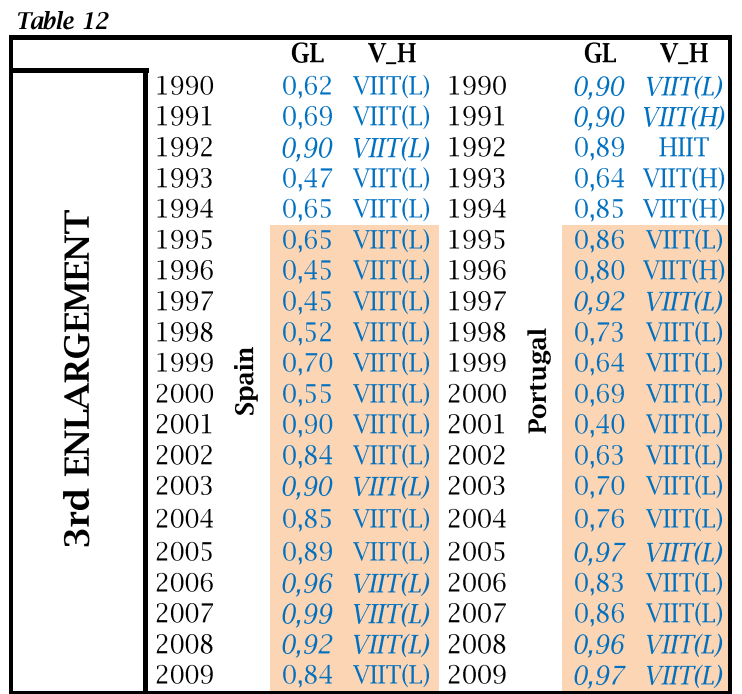

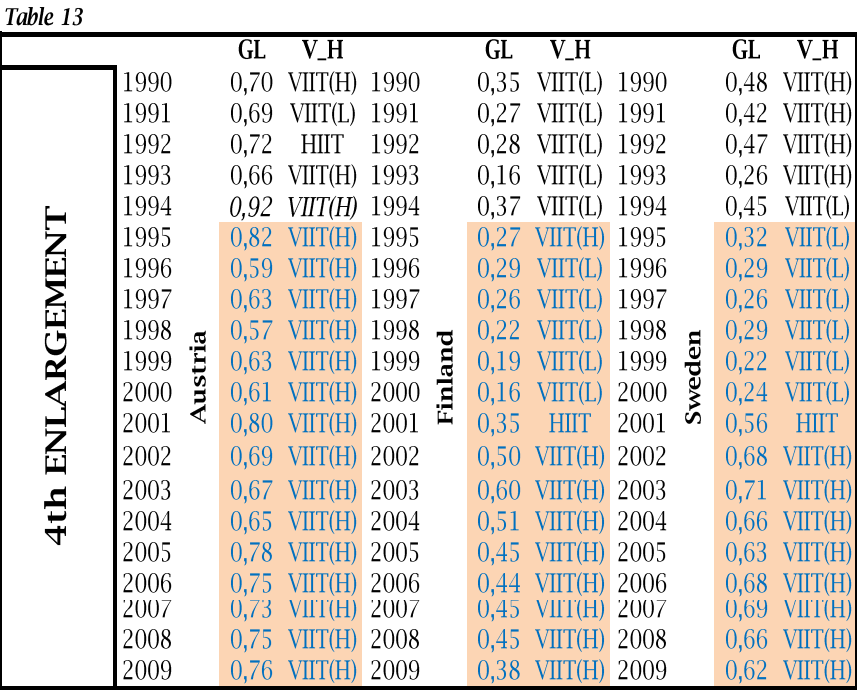




\begin{tabular}{|c|c|c|c|c|c|c|c|c|c|c|c|c|c|c|c|c|c|}
\hline \multirow{41}{*}{ 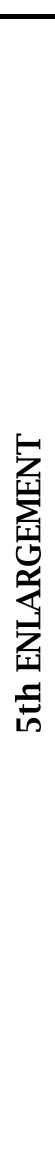 } & 11990 & $\begin{array}{c}\text { GL } \\
0.24\end{array}$ & $\begin{array}{c}\mathbf{V} \text { V_H } \\
\text { VIT(H) }\end{array}$ & & & GL & $\overline{\mathrm{V}_{-} \mathrm{H}}$ & & & GL & $\overline{V_{-}+H}$ & & GL & $\overline{\mathrm{V}} \_\mathrm{H}$ & & & \\
\hline & 1991 & 0,15 & VIIT(H) & & & & & & & & & & & & & & \\
\hline & 1992 & 0,28 & VIIT(H) & 1992 & & 0,93 & $V I I T(H)$ & & & & & 1992 & 0,91 & $\operatorname{VIIT}(H)$ & & & \\
\hline & 1993 & 0,33 & HIIT & 1993 & & 0,36 & VIIT(H) & 1993 & & 0,51 & VIIT(H) & 1993 & 0,76 & VIIT(H) & & & \\
\hline & 1994 & 0,75 & VIIT(H) & 1994 & & 0,58 & VIIT(H) & 1994 & & 0,93 & $\operatorname{VIIT}(H)$ & 1994 & 0,77 & VIIT(H) & & & \\
\hline & 1995 & 0,95 & VIIT $(H)$ & 1995 & & 0,38 & VIIT(H) & 1995 & & 0,40 & VIIT(H) & 1995 & 0,95 & HIIT & & & \\
\hline & 1996 & 0,78 & VIIT(H) & 1996 & & 0,65 & VIIT(H) & 1996 & & 0,79 & VIIT(H) & 1996 & 0,69 & VIIT(L) & & & \\
\hline & 1997 & 0,75 & VIIT(H) & 1997 & & 0,89 & VIIT(H) & 1997 & & 0,46 & VIIT(H) & 1997 & 0,84 & VIIT(H) & & & \\
\hline & 1998 ชิ & 0,68 & VIIT(H) & 1998 & & 0,57 & VIIT(H) & 1998 & & 0,18 & VIIT(L) & 1998 בَّ & 0,56 & VIIT(H) & & & \\
\hline & 1999 ح & 0,73 & VIIT(H) & 1999 & 急 & 0,18 & VIIT(H) & 1999 & - & 0,25 & VIIT(L) & 1999 ฐ్ & 0,53 & VIIT(H) & & & \\
\hline & 2000 క్ & 0,74 & VIIT(H) & 2000 & $\frac{0}{n}$ & 0,86 & VIIT(L) & 2000 & 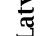 & 0,85 & VIIT(H) & 2000 켜 & 0,45 & VIIT(H) & & & \\
\hline & 2001 J & 0,86 & HIIT & 2001 & m & 0,17 & VIIT(L) & 2001 & & 0,02 & VIIT(L) & $2001 \quad \Xi$ & 0,57 & VIIT(H) & & & \\
\hline & 2002 & 0,55 & VIIT(L) & 2002 & & 0,11 & VIIT(H) & 2002 & & 0,02 & VIIT(L) & 2002 & 0,65 & VIIT(H) & & & \\
\hline & 2003 & 0,57 & HIIT & 2003 & & 0,14 & VIIT(L) & 2003 & & 0,09 & VIIT(L) & 2003 & 0,80 & VIIT(H) & & & \\
\hline & 2004 & 0,48 & HIIT & 2004 & & 0,53 & VIIT(H) & 2004 & & 0,05 & VIIT(L) & 2004 & 0,92 & VIIT(H) & & & \\
\hline & 2005 & 0,56 & HIIT & 2005 & & 0,31 & VIIT(L) & 2005 & & 0,05 & VIIT(L) & 2005 & 0,95 & $V I I T(H)$ & & & \\
\hline & 2006 & 0,69 & HIIT & 2006 & & 0,58 & VIIT(H) & 2006 & & 0,11 & VIIT(L) & 2006 & 0,72 & VIIT(H) & & & \\
\hline & 2007 & 0,65 & VIIT(L) & 2007 & & 0,23 & VIIT(H) & 2007 & & 0,49 & VIIT(H) & 2007 & 0,39 & VIIT(H) & & & \\
\hline & 2008 & 0,68 & VIIT(L) & 2008 & & 0,10 & VIIT(H) & 2008 & & 0,11 & VIIT(L) & 2008 & 0,17 & VIIT(H) & & & \\
\hline & 2009 & 0,62 & HIIT & 2009 & & 0,44 & VIIT(H) & 2009 & & 0,54 & $\mathrm{VIIT}(\mathrm{H})$ & 2009 & 0,22 & VIIT(H) & & & \\
\hline & & GL & $\overline{V_{-} H}$ & & & GL & V_H & & & GL & V_H & & GL & V_H & & $\overline{G L}$ & $\overline{\mathrm{V} \_\mathrm{H}}$ \\
\hline & & & & & & & & 1990 & & 0,36 & VIIT(H) & 1990 & 0,12 & VIIT(L) & 1990 & 0,69 & VIIT(H) \\
\hline & & & & & & & & 1991 & & 0,37 & VIIT(H) & 1991 & 0,19 & VIIT(L) & & 0,96 & $V I I T(H)$ \\
\hline & & & & & & & & 1992 & & 0,36 & VIIT(H) & 1992 & 0,11 & VIIT(L) & 1 & 0,65 & (H) \\
\hline & 1993 & 0,79 & VIIT(H) & 1993 & & 0,69 & VIIT(H) & 1993 & & 0,58 & VIIT(H) & 1993 & 0,05 & VIIT(L) & 1993 & 0,58 & VIIT(H) \\
\hline & 1994 & 0,55 & HIIT & 1994 & & 0,60 & VIIT(H) & 1994 & & 0,96 & $\operatorname{VIIT}(H)$ & 1994 & 0,51 & HITT & $1 s$ & 0,23 & VII' \\
\hline & 1995 & 0,53 & VIIT(H) & 1995 & & 0,81 & VIIT(H) & 1995 & & 0,48 & VIIT(H) & 1995 & 0,83 & HIT & & 0,35 & VIIT(H) \\
\hline & 1996 & 0,95 & $V I I T(H)$ & 1996 & & 0,91 & $\operatorname{VIIT}(L)$ & 1996 & & 0,71 & VIIT(H) & 1996 & 0,27 & VIIT(H) & 1996 & 0,42 & VIIT(H) \\
\hline & 1997 & 0,98 & VIIT(H) & 1997 & & 0,90 & $V I I T(L)$ & 1997 & & 0,85 & VIIT(H) & 1997 & 0,36 & HITT & 1997 & 0,36 & VIIT(H) \\
\hline & 1998 & 0,68 & VIIT(H) & 1998 & & 0,79 & VIIT(L) & 1998 & & 0,96 & VIIT $(H)$ & 1998 & 0,20 & VIIT(L) & 1998 & 0,43 & VIIT(H) \\
\hline & 1999 롱 & 0,41 & VIIT(H) & 1999 & ฮี & 0,83 & VIIT(L) & 1999 & 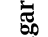 & 0,86 & VIIT(H) & $1999 \cong$ & 0,46 & VIIT(L) & 1999 & 0,51 & VIIT(H) \\
\hline & 2000 है & 0,44 & VIIT(H) & 2000 & อั & 0,88 & VIIT(L) & 2000 & $\Xi$ & 0,67 & HIIT & $2000 \stackrel{\pi}{2}$ & 0,56 & VIIT(L) & 2000 & 0,99 & $\operatorname{VIIT}(H)$ \\
\hline & 2001 ๘ & 0,60 & VIIT(H) & 2001 & के & 0,90 & $\operatorname{VIIT}(L)$ & 2001 & 牙 & 0,92 & $V I I T(H)$ & 2001 & 0,43 & VIIT(L) & 2001 & 0,87 & HIIT \\
\hline & 2002 & 0,41 & VIIT(H) & 2002 & & 0,93 & $\operatorname{VIIT}(L)$ & 2002 & & 0,81 & VIIT(H) & 2002 & 0,41 & VIIT(L) & 2002 & 0,82 & VIIT(H) \\
\hline & 2003 & 0,43 & VIIT(H) & 2003 & & 0,97 & $\operatorname{VIIT}(L)$ & 2003 & & 0,82 & VIIT(H) & 2003 & 0,87 & VIIT(L) & 2003 & 0,91 & $\operatorname{VIIT}(H)$ \\
\hline & 2004 & 0,61 & VIIT(H) & 2004 & & 0,95 & VIIT(L) & 2004 & & 0,66 & НIIT & 2004 & 0,89 & VIIT(H) & 2004 & 0,83 & HIIT \\
\hline & 2005 & 0,48 & VIIT(H) & 2005 & & 0,80 & VIIT(L) & 2005 & & 0,56 & HIIT & 2005 & 0,61 & VIIT(L) & 2005 & 0,78 & HIIT \\
\hline & 2006 & 0,53 & VIIT(H) & 2006 & & 0,66 & VIIT(L) & 2006 & & 0,53 & VIIT(L) & 2006 & 0,23 & VIIT(L) & 2006 & 0,84 & HIIT \\
\hline & 2007 & 0,60 & VIIT(H) & 2007 & & 0,65 & VIIT(H) & 2007 & & 0,71 & VIIT(L) & 2007 & 0,49 & VIIT(L) & 2007 & 0,90 & $V I I T(L)$ \\
\hline & 2008 & 0,50 & VIIT(H) & 2008 & & 0,55 & VIIT(H) & 2008 & & 0,73 & VIIT(L) & 2008 & 0,73 & VIIT(L) & 2008 & 0,87 & VIIT(L) \\
\hline & 2009 & 0,41 & VIIT(H) & 2009 & & 0,56 & VIIT(H) & 2009 & & 0,62 & VIIT(L) & 2009 & 0,96 & HIIT & 2009 & 0,83 & HIIT \\
\hline
\end{tabular}

\begin{tabular}{|c|c|c|c|c|c|c|}
\hline \multirow{21}{*}{ 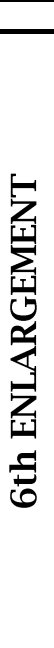 } & & $\overline{\mathrm{GL}}$ & $\overline{\mathrm{V}} \_\mathrm{H}$ & & $\overline{\mathrm{GL}}$ & $\overline{\mathrm{V}_{-} \mathrm{H}}$ \\
\hline & 1990 & 0,32 & VIIT(H) & 1990 & 0,56 & VIIT(H) \\
\hline & 1991 & 0,52 & VIIT(H) & 1991 & 0,71 & VIIT(H) \\
\hline & 1992 & 0,73 & VIIT(H) & 1992 & 0,50 & VIIT(H) \\
\hline & 1993 & 0,60 & VIIT(H) & 1993 & 0,55 & VIIT(H) \\
\hline & 1994 & 0,77 & VIIT(H) & 1994 & 0,75 & VIIT(H) \\
\hline & 1995 & 0,91 & $V I I T(H)$ & 1995 & 0,67 & VIIT(H) \\
\hline & 1996 & 0,92 & $V I I T(H)$ & 1996 & 0,59 & VIIT(H) \\
\hline & 1997 & 0,93 & $V I I T(H)$ & 1997 & 0,64 & VIIT(H) \\
\hline & פת. 1998 & 0,81 & VIIT(H) & צ. 1998 & 0,91 & VIIT $(H)$ \\
\hline & 1999 ฐ్త్ & 0,87 & VIIT(H) & 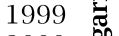 & 0,92 & $\operatorname{VIIT}(H)$ \\
\hline & 2000 ฐี & 0,69 & VIIT(H) & $2000 \stackrel{00}{3}$ & 0,84 & VIIT(H) \\
\hline & $2001 \approx$ & 0,93 & $V I I T(H)$ & 2001 Ф & 0,93 & VIIT(H) \\
\hline & 2002 & 0,99 & $V I I T(H)$ & 2002 & 1,00 & VIIT(H) \\
\hline & 2003 & 0,91 & $V I I T(H)$ & 2003 & 0,98 & VIIT(H) \\
\hline & 2004 & 0,95 & $V I I T(H)$ & 2004 & 0,96 & VIIT(H) \\
\hline & 2005 & 0,94 & $V I I T(H)$ & 2005 & 0,92 & VIIT(H) \\
\hline & 2006 & 0,98 & $V I I T(H)$ & 2006 & 0,98 & VIIT $(H)$ \\
\hline & 2007 & 0,83 & VIIT(H) & 2007 & 0,95 & VIIT(H) \\
\hline & 2008 & 0,81 & VIIT(H) & 2008 & 0,83 & VIIT(H) \\
\hline & 2009 & 0,89 & VIIT(H) & 2009 & 0,88 & VIIT(H) \\
\hline
\end{tabular}

Red box shows the perfect IIT.

Note: In these tables from 9 to 15 , italic figures indicate very high values of GL indices which shows the strength of IIT. Blue figures show the EU membership period of these countries. Orange boxes indicate the values of GL indices and the type of IIT after Customs Union.
After Customs Union, bilateral IIT with Germany becomes HIIT. Turkey-France, TurkeyDenmark trade becomes mainly low-quality VIIT after Customs Union. Since bilateral manufacturing trade with Italy, Ireland, Spain is always low-quality VIIT, nothing has changed after Customs Union. Also, trade with United Kingdom is mainly low-quality VIIT and it continues after Customs Union. On the contrary, trade with Austria, Romania and Bulgaria is always highquality VIIT and it also continues to be high-quality after Customs Union. Trade with Netherlands has turned to be high-quality VIIT, especially after 2002. The values of GL index for Finland, Latvia and Sweden indicate that IIT is very low with Finland which is also low-quality VIIT type. But after 2002 IIT has increased and the type of IIT has turned to be high-quality VIIT. Before and after Customs Union, manufacturing bilateral trade with Hungary and Poland is mainly high-quality VIIT until 2004 when they become a member of EU. After their EU membership trade with Hungary and Poland has turned to be low-quality VIIT and HIIT, respectively.

\section{Conclusion}

Europe is Turkey's major trading partner of Turkey with a significant share in total trade flows. The CU between Turkey and EU has strengthened the economic and commercial ties and promoted an increase in the trade volume of Turkey with the EU. In this study, the 
relation between the integration process and the intensity of IIT between Turkey and EU countries examined by comparing before-and-after periods of Turkey's CU membership. The main conclusions of this study are the followings:

- Turkey's principal trading partner in the EU is Germany, followed by Italy, France, the United Kingdom, and the Netherlands.

- Imports from EU is approximately $60 \%$ of manufacturing trade. After 2004, imports decreases to $47 \%$. On the other hand, until 2008, exports to EU is $50 \%-60 \%$ of total manufacturing trade. But after 2008, manufacturing exports to EU have declined to $46 \%$.

- Turkey's main export items to the EU market are apparel and clothing, electrical machinery and equipment, textile yarns, iron, and steel man-made staple fibers. On the other hand, the main import items are machines, electrical machinery, road vehicles, plastics, organic chemicals, optical instruments, paper, and pharmaceutical products.

- Turkish imports from EU is greater than Turkish exports to EU. So, Turkish manufacturing trade has a trade deficit. On the contrary, there is a manufacturing trade surplus from 2004 to 2008 .

- Turkish manufacturing trade with EU countries decreases. In other words, trade with non-EU countries increases.

- For Turkish manufacturing exports, sector 18, 17 and 15 are the very important ones. On the other hand, for Turkish manufacturing imports, sectors 29, 24, 27 and 24 are the important ones.

- For the non-EU countries sectors 17 and 27 are the dominant sectors in total manufacturing trade.

- The value of GL index is high for EU-Turkey manufacturing trade. Especially, after 2001 the value of GL is between $85 \%-95 \%$. Also, the type of IIT is low-quality VIIT to a large extent.

- Before and after Customs Union period the type of IIT has not changed. The dominance of low-quality VIIT still holds for EU-Turkey manufacturing trade.

- After Customs Union, in sectors 15, 16, 20 and 22 IIT is decreasing. In sectors $21,25,27,28$, $30,31,33,34,35$ and 36 IIT is increasing.

- In sectors 16 and 21 , low-quality VIIT has turned to be high-quality VIIT after Customs Union. Conversely, in sectors 17, 22 and 35, high-quality VIIT has turned to be low-quality VIIT. For the other sectors nothing have changed after Customs Union.

- After Customs Union,

○ Turkey-Germany trade becomes HIIT.

- Turkey-France, Turkey-Denmark trade becomes mainly low-quality VIIT after Customs Union.
- Since bilateral manufacturing trade with Italy, Ireland, Spain is always low-quality VIIT, nothing has changed after Customs Union.

- Trade with United Kingdom is mainly low-quality VIIT and it continues after Customs Union.

- Trade with Austria, Romania and Bulgaria is always high-quality VIIT and it also continues to be highquality after Customs Union.

- Trade with Netherlands has turned to be high-quality VIIT, especially after 2002.

- The values of GL index for Finland, Latvia and Sweden indicate that IIT is very low with Finland which is also low-quality VIIT type. But after 2002 IIT has increased and the type of IIT has turned to be high-quality VIIT.

- Before and after Customs Union, manufacturing bilateral trade with Hungary and Poland is mainly highquality VIIT until 2004 when they become a member of EU. After their EU membership trade with Hungary and Poland has turned to be lowquality VIIT and HIIT, respectively.

\section{REFERENCES}

Adam, A. and T. Moutos (2008), "The Trade Effects of the EU-Turkey Customs Union", The World Economy, pp. 685-700.

Al-Mawali, N. (2005), “Country-Specific Determinants of Vertical and Horizontal Intra-Industry Trade of South Africa: An Empirical Investigation", South African Journal of Economics, Vol. 73, No. 3, pp. 406-25.

Aturupane, C., S. Djankov and B. Hoekman (1999), "Horizontal and Vertical Intra-Industry Trade Between Eastern Europe and the European Union", Review of World Economics, Vol. 135, No. 1, pp. 62-81.

Aynagoz Cakmak, O. and S. Yilmaz (2006), "Outsourcing after the Customs Union between EU and Turkey", Presentation at the European Trade Study Group 8th Annual Conference,ETSG 2006,Vienna.

Azhar, A. K. M. and R. J. R. Elliott (2006), “On the Measurement of Product Quality in Intra Industry Trade", Review of World Economics, Vol. 142, No. 3, pp. 476-495.

Balassa, B. (1966), "Tariff Reductions and Trade in Manufacturing Among the Industrial Countries", American Economic Review, Vol. 56, No. 3, pp. 466473. 
Brülhart, M. (1994), "Marginal Intra-Industry Trade: Measurement and Relevance for the Pattern of Industrial Adjustment", Review of World Economics/Weltwirtschaftliches Archiv, Vol. 130, No. 3 , pp. 600-613.

Crespo, N. and M. P. Fontoura (2001), "Determinants of the Pattern of Horizontal and Vertical Intra-Industry Trade: What Can We Learn From Portuguese Data?", Mimeo, ISEG Technical University of Lisbon.

Dixit, A., and J. Stiglitz (1977), "Monopolistic Competition and Optimum Product Diversity", American Economic Review, Vol. 67, No. 3, pp. 297308

Doganer Gonel, F. (2001), "How Important is Intra-Industry Trade Between Turkey and Its Trading Partners? A Comparison Between the European Union and Central Asia Turkic Republics", Russian and East European Finance and Trade, Vol. 37, No. 4, JulyAugust, pp. 61-76.

Durkin J. T. and M. Krygier (2000), "Differences in GDP Per Capita and the Share of IntraIndustry Trade: The Role of Vertically Differentiated Trade", Review of International Economics, Vol. 8, No. 4, pp. 760-774.

Erlat, G. and H. Erlat (2010), "Measuring Product Quality in Turkish Intra-Industry Trade", 30th Annual Meeting of the Middle East Economic Association, Atlanta, USA.

Falvey, R. (1981), "Commercial Policy and Intra-Industry Trade", Journal of International Economics, Vol. 11, No. 4, pp. 495-511.

Finger, J. (1975), "Trade Overlap and IntraIndustry Trade", Economic Inquiry, Vol. 13, No. 4, pp. 581-589.

Fontagné, L. and M. Freudenberg (1997), "Intra-Industry Trade: Methodological Issues Reconsidered”, CEPII Working Paper, No. 97-01.

Gokalp M.F., A. Yildirim, (2004), "Effects of the Customs Union on Turkey and the EU Relations", Avrupa Birliği Sürecinde Türkiye, Siyasal Ekonomik ve Toplumsal Dönüşüm, Sorunlar ve Tartışmalar, (edt: T.Uzun, S.Özen), Seçkin Yayınevi, Ankara, ss.263-288.

Gray, H. (1973), "Two-Way International Trade in Manufactures: A Theoretical Underpinning", Review of World Economics/Weltwirtschaftliches Archiv, Vol. 109, No. 1, pp. 19-39.

Greenaway, D., R. Hine and C. Milner (1994), "Country-Specific Factors and the Pattern of Horizontal and Vertical Intra-Industry Trade in the UK", Review of World Economics/Weltwirtschaftliches Archiv, Vol. 130, No. 1, pp. 77-100.

Greenaway, D., R. Hine and C. Milner (1995), "Vertical and Horizontal Intra-Industry Trade: A Cross Industry Analysis for the United Kingdom", Economic Journal, Vol. 105, (November), pp. 1505-1518.
Grubel, H. (1967), "Intra-Industry Trade Specialization and the Pattern of Trade", Canadian Journal of Economics and Political Science, Vol. 33, No. 3, pp. 374-388.

Grubel, H. and P. Lloyd (1975), Intra-Industry Trade: The Theory and Measurement of International Trade in Differentiated Products, The Macmillan Press Ltd, London.

Grubel, H. and P. Lloyd (2003), Intra-Industry Trade, The International Library of Critical Writings in Economics Series, 160.

Gullstrand, J. (2002), "Does the Measurement of Intra-Industry Trade Matter?",Review of World Economics/Weltwirtschaftliches Archiv, Vol. 138, pp. 317-39.

Halicioglu, F. (1997), "Static Effects of Turkey - EU CU and Its Alternatives" (in Turkish), İÜ İktisat Fakültesi Sosyal Bilimler Dergisi, No. 3, pp. 61-72.

Helpman, E. (1987), "Imperfect Competition and International Trade: Evidence from Fourteen Industrial Countries", Journal of the Japanese and International Economics, Vol. 1, No. 1, pp. 62-81.

Helpman, E. and P. Krugman (1985), Market Structure and Foreign Trade: Increasing Returns, Imperfect Competition, and the International Economy. Cambridge, MA: MIT Press.

$\mathrm{Hu}, \mathrm{X}$. and Y. MA (1999), "International IntraIndustry Trade of China". Review of World Economics/Weltwirtschaftliches Archiv, Vol. 135, No. 1, pp. 82-101.

Jackson, K. (2007), "Assessing the Turkey-EU Customs Union Shallow and Deep Integration", Presentation at the European Trade Study Group 9th Annual Conference,ETSG 2007,Athens.

Jensen, L. and T. Lüthje (2008), "Country Specific Effects of Differences in Factor Endowments on Intra-Industry Trade", Global Business and Finance Review, Vol. 13, No. 1, pp. 35-46.

Karaman, F. N. and N. L .Ozkale (2006), "Measuring the Static Effects of European Customs Union on Turkey's Foreign Trade", Presentation at the European Trade Study Group 8th Annual Conference,ETSG 2006,Vienna.

Koçyiğit, A. and A. Şen (2007), "The Extent Of Intra-Industry Trade Between Turkey and The European Union: The Impact Of Customs Union", Journal of Economic and Social Research, Vol. 9, No. 2, pp.61-85.

Krugman, P. (1979), "Increasing Returns, Monopolistic Competition and International Trade", Journal of International Economics, Vol. 9, No. 4, pp. 469-479.

Lohrmann, A. M. (2002), “A Dynamic Analysis of Turkey's Trade with the European Union in the 1990s", Russian and East European Finance and Trade, Vol. 38, No. 2, March-April,pp. 44-58. 
Mora, C. (2002), "The Role of Comparative Advantage in Trade within Industries: A Panel Data Approach for the European Union", Review of World Economics/Weltwirtschaftliches Archiv, Springer, Vol. 138, (June), No. 2, pp. 291-316.

Neyaptı, B., F. Taşkın., and M. Üngör (2007), "Has European Customs Union Agreement really affected Turkey's trade?", Applied Economics, Vol. 39, pp. 2121-2132.

Seymen, D. and U. Utkulu (2004), "Trade and Competitiveness Between Turkey and the EU: Time Series Evidence", Turkish Economic Association Discussion Paper, No. 8.

Seymen, D. And Ö. Bilici (2009), "Has Customs Union Changed the Country Concentration of Trade between Turkey and the European Union?", Presentation at the European Trade Study Group 11th Annual Conference, ETSG 2009,Rome.

Spence M. (1976), "Product Selection, Fixed Costs, and Monopolistic Competition", The Review of Economic Studies, Vol. 43, No. 2, pp. 217-235.

Stiglitz, J. E. (1987), "The Causes and Consequences of the Dependence of Quality on Price", Journal of Economic Literature, Vol. 25, pp. 1-48.

Togan, S. (2000), "Effects of a TurkeyEuropean Union Customs Union and Prospects for the Future", Russian and East European Finance and Trade, Vol. 36, No. 4, July-August, pp. 5-25.

Vatansever Deviren, N. (2004), "Intra-industry trade of manufactured products between Turkey and EU", (in Turkish), İktisat İşletme ve Finans, Eylül, pp.107127.

Veeramani, C. (2002), "Intra-Industry Trade of India: Trends and Country-Specific Factors", Review of World Economics/Weltwirtschaftliches Archiv, Vol. 138, No. 3 .

Vergil, H. (2004), “Turkey's Intra-Industry Trade Level After Customs Union" (in Turkish), Journal of Faculty of Business, Vol. 5, No. 2.

Yenilmez, F. And E. Kutlu (2005), "On the importance of Intra-Industry Trade between Turkey and the EU Countries" (in Turkish), İktisat İşletme ve Finans, Nisan, pp.45-64.

Xu, Y. (2002), "A Comparison of Two Models of Intra-Industry Trade", Journal of International Trade and Economic Development", Taylor and Francis Journals, Vol. 11, (December), No. 4, pp. 405-427.

\begin{tabular}{|c|c|c|}
\hline & Enlargement of the & ropean Union \\
\hline \multirow{6}{*}{1957} & \multirow{6}{*}{ Founding States } & Belgium \\
\hline & & France \\
\hline & & Germany \\
\hline & & Italy \\
\hline & & Luxembourg \\
\hline & & Netherlands \\
\hline \multirow{3}{*}{1973} & \multirow{3}{*}{ First Enlargement } & Denmark \\
\hline & & Ireland \\
\hline & & United Kingdom \\
\hline 1981 & $\begin{array}{c}\text { Second } \\
\text { Enlargement }\end{array}$ & Greece \\
\hline \multirow{2}{*}{1986} & \multirow{2}{*}{ Third Enlargement } & Portugal \\
\hline & & Spain \\
\hline \multirow{3}{*}{1995} & \multirow{3}{*}{$\begin{array}{c}\text { Fourth } \\
\text { Enlargement }\end{array}$} & Austria \\
\hline & & Finland \\
\hline & & Sweden \\
\hline \multirow{10}{*}{2004} & \multirow{10}{*}{ Fifth Enlargement } & Cyprus \\
\hline & & Czech Republic \\
\hline & & Estonia \\
\hline & & Hungary \\
\hline & & Latvia \\
\hline & & Lithuania \\
\hline & & Malta \\
\hline & & Poland \\
\hline & & Slovakia \\
\hline & & Slovenia \\
\hline \multirow{2}{*}{2007} & \multirow{2}{*}{ Sixth Enlargement } & Bulgaria \\
\hline & & Romania \\
\hline
\end{tabular}

